\title{
Application of Data-Independent Acquisition Approach to Study the Proteome Change from Early to Later Phases of Tomato Pathogenesis Responses
}

\author{
Kai-Ting Fan ${ }^{1}$, Kuo-Hsin Wang ${ }^{1}$, Wei-Hung Chang ${ }^{1}$, Jhih-Ci Yang ${ }^{2,3}$, Ching-Fang Yeh ${ }^{1}$, \\ Kai-Tan Cheng ${ }^{1}$, Sheng-Chi Hung ${ }^{3,4}$ and Yet-Ran Chen $1,2,3,4, * \mathbb{D}$ \\ 1 Agricultural Biotechnology Research Center, Academia Sinica, Taipei 11529, Taiwan; \\ kaitingfan@sinica.edu.tw (K.-T.F.); khwang@gate.sinica.edu.tw (K.-H.W.); \\ whchang@gate.sinica.edu.tw (W.-H.C.); cfyeh@gate.sinica.edu.tw (C.-F.Y.); \\ ktc77123@gate.sinica.edu.tw (K.-T.C.) \\ 2 Sustainable Chemical Science and Technology, Taiwan International Graduate Program, \\ Institute of Chemistry, Academia Sinica, Taipei 11529, Taiwan; jhihciy@gate.sinica.edu.tw \\ 3 Sustainable Chemical Science and Technology, Taiwan International Graduate Program, \\ Department of Applied Chemistry, National Chiao Tung University, Hsinchu 30010, Taiwan; \\ kempis710165@gate.sinica.edu.tw \\ 4 Institute of Biotechnology, National Taiwan University, Taipei 10617, Taiwan \\ * Correspondence: yetran@gate.sinica.edu.tw; Tel.: +886-02-2707-2050
}

Received: 27 December 2018; Accepted: 12 February 2019; Published: 17 February 2019

\begin{abstract}
Plants and pathogens are entangled in a continual arms race. Plants have evolved dynamic defence and immune mechanisms to resist infection and enhance immunity for second wave attacks from the same or different types of pathogenic species. In addition to evolutionarily and physiological changes, plant-pathogen interaction is also highly dynamic at the molecular level. Recently, an emerging quantitative mass spectrometry-based proteomics approach named data-independent acquisition (DIA), has been developed for the analysis of the proteome in a high-throughput fashion. In this study, the DIA approach was applied to quantitatively trace the change in the plant proteome from the early to the later stage of pathogenesis progression. This study revealed that at the early stage of the pathogenesis response, proteins directly related to the chaperon were regulated for the defence proteins. At the later stage, not only the defence proteins but also a set of the pathogen-associated molecular pattern-triggered immunity (PTI) and effector triggered immunity (ETI)-related proteins were highly induced. Our findings show the dynamics of the plant regulation of pathogenesis at the protein level and demonstrate the potential of using the DIA approach for tracing the dynamics of the plant proteome during pathogenesis responses.
\end{abstract}

Keywords: plant pathogenesis responses; data-independent acquisition; quantitative proteomics; Pseudomonas syringae

\section{Introduction}

Plants are sessile organisms that are in close contact with a variety of organisms, including pathogens and have thus evolved an efficient innate immune system to defend themselves from those biotic stresses. The typical passive defence of plants actually starts from physical barriers, including the trichomes, waxy cuticle and cell wall [1]. On the other hand, successful active defence responses are initiated from the ability of plants to sense pathogens using extracellular and intracellular innate immune receptors, to induce subsequent cellular reprogramming for defence. Plants have evolved to express receptors that recognize conserved pathogen-associated molecular 
patterns (PAMPs) or microbial associated molecular patterns (MAMPs) such as FLS2 receptor that perceives bacterial flagellin via the minimal epitope flg22, one of conserved pathogen molecules essential for its reproduction [2]. Another type of plant sensing ability is initiated by endogenous damaged-associated molecular patterns (DAMPs) which are molecules produced by cell-damage or necrosis caused by pathogen invasion or herbivore attack, including fragments of cell wall structure, signalling peptides/polypeptides from cleaved precursor proteins like systemin [3], PLANT ELICITOR PEPTIDES (PEPs) [4] and CAP-derived peptide 1 (CAPE1) [5] and extracellular molecules like nucleotides [6]. Currently known DAMPs have been demonstrated to be able to induce similar innate immune responses in plants as microbe-derived PAMPs/MAMPs and it has been proposed that DAMPs could be used to amplify the responses triggered by PAMPs [7].

After perceiving the danger signals of pathogen attacks, plants initiate a series of defence responses. The first one, often thought as the basal pathogen resistance of plants, is triggered by the binding of PAMPs/MAMPs by the plasma membrane-localized receptor (pattern recognition receptors; PRRs) and is therefore called PAMP-triggered immunity (PTI) [8]. PTI includes the increased ion influx, a burst of reactive oxygen species, activation of the mitogen-activated protein kinase (MAPK) cascade and increased level of defence phytohormones like salicylic acid (SA), jasmonic acid (JA) or ethylene (ET). However, pathogens that have become successfully adapted though evolution can suppress or bypass the PTI responses by injecting proteins-termed effectors through a type III secretion system to the apoplast or cellular region of the host, resulting in effector-triggered susceptibility (ETS) $[9,10]$. To counter-attack ETS, plant species have also evolved another kind of defence response, effector-triggered immunity (ETI), which uses intracellular or transmembrane receptors ( $R$ proteins) to specifically target the effector proteins of pathogens, resulting in much stronger resistance responses, usually leading to hypersensitive response (HR) cell death. A "zig-zag" model has been proposed to interpret how /why the plant immune system is made up of this complex, multi-layered innate immune system of PTI and ETI responses through evolutionary development [10]. Although from the transcriptomics data, a significant number of genes could both be regulated by PTI and ETI, the later causes faster and greater amplitude of induction, leading scientists to speculate that PTI and ETI could result in synergistic effects [11-13]. However, when examining specific defence-related phytohormones (SA, JA and ET) in Arabidopsis, it has been shown that in PTI there are more evident synergistic relationships; while in ETI there are more compensatory relationships among the signalling sectors [14-16]. There are still gaps in understanding how these sophisticated mechanisms are regulated such as how PTI and ETI together form an effective defence network, since a large number of the transcripts involved in the regulation of immune and defence response are known to be time-dependent [17]. This is also related to the fact that regulation at the protein level should also be time dependent and highly dynamic.

The isobaric labelling approach has been used to study the dynamics of proteome regulation in plants during pathogenesis responses. This approach has been used to trace the change in the proteome of tomato in response to infection with Pseudomonas syringae pv. tomato (Pst) DC3000 at early and late time points. Using a combination of strong off-line cation exchange chromatography and liquid chromatography coupled with mass spectrometry (LC-MS), a total of $\sim 2300$ proteins were identified [18]. Although the isobaric approach is a promising technology to perform multiplex quantitative proteomics analysis, it is often required to fractionate the sample to minimize the effect of ratio compression [19]. The use of an additional fractionation step will require a higher quantity of sample to compensate for sample loss during the fractionation step and reduce the throughput of the proteome analysis. This limits its application to the analysis of a large quantity of the proteomics samples. Recently, a new MS analysis approach called data independent acquisition (DIA) was proposed to solve this issue. The DIA approach is considered a promising approach for performing quantitative proteome profiling in a high-throughput manner. The DIA approach is based on the acquisition of fragment-ion information for all precursor ions within a certain range of $\mathrm{m} / \mathrm{z}$ values, as demonstrated by the sequential window acquisition of all theoretical mass spectra (SWATH) 
approach [20]. It has been demonstrated that the application of the DIA approach was able to identify and quantify thousands of proteins without performing fractionation and only a few micrograms of the protein sample is required [20]. In the DIA approach, selected reaction monitoring (SRM)-like extracted ion chromatography (XIC) on sequence specific ion transitions can be used for the identification and SRM-like quantification of the peptides after the data acquisition. To demonstrate this technology in the study of the plant pathogenesis responses, here we used the tomato proteome regulated by infection of Pst DC3000. P. syringae, a hemi-biotroph bacteria, is one of the most studied bacterial pathogens due to its ability to infect a great variety of plant species including reference plants like Arabidopsis and tobacco and crops like tomato and potato. P. syringae relies on effector proteins belonging to the bacterial type III secretion system to suppress the plant defence system thus achieving pathogenesis. More than 40 P. syringae effectors have been identified with their host targets in plants, demonstrating complex plant-pathogen interactions which makes $P$. syringae an important model system for examining the molecular mechanisms of plant pathogen defence [21]. We quantitatively profiled the total tomato proteomes regulated by the infection of Pst DC3000 from early to later time points using the LC-MS/MS operated in DIA mode. Using this approach, the change in the proteomes of mock and Pst DC3000-inoculated samples were analysed to identify the proteins with significant change in abundance in the early to the later stage of the pathogenesis responses. Without the hideous labour requirement for sample preparation that is required for peptide fractionation, the one-shot sample analysis using the DIA approach should provide researchers an efficient way to identify not only well-known but also potential protein markers for further biological studies.

\section{Results and Discussion}

\subsection{Experimental Design and the Identification and Quantification Result}

To mimic natural bacterial infection of tomato leaves without causing physical damage in cells, we optimized the dipping method without using the vacuum infiltration. Pst DC3000 infection symptoms and bacterial growth were recorded until 7 days post-inoculation (dpi) (Figure 1, Supplementary Figure S1). The growth of Pst DC3000 started $4 \mathrm{~h}$ post-inoculation (hpi) and dramatically increased at $3 \mathrm{dpi}$ (Figure 1B) although the disease phenotype became more obvious at 3 , 5 or 7 dpi.

A
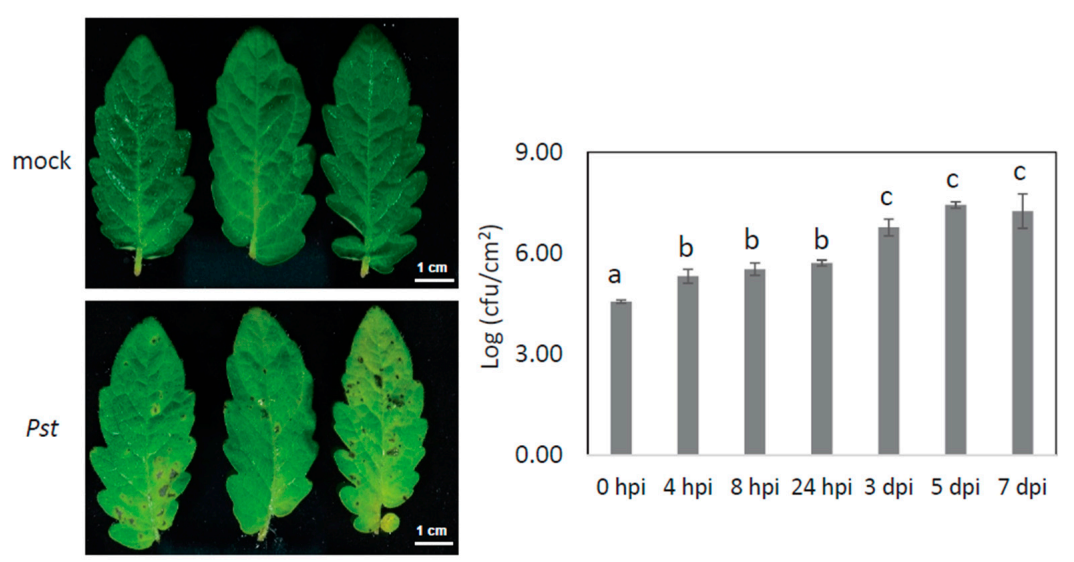

Figure 1. Disease phenotypes and population dynamics of Pst DC3000 on tomato leaves. (A) Visible disease symptoms in tomato leaves after leaves were dipped into bacterial suspension at an $\mathrm{OD}_{600}$ of 0.02. Photos were taken at 5 days post-inoculation. (B) Bacteria titres in leaves at $0,4,8,24 \mathrm{~h}$ or 3, 5, 7 days after inoculation with Pst DC3000. Error bars represent the standard deviation of three biological replicates. A statistical significance difference is shown between different time points using analysis of variance (ANOVA) with post-hoc Tukey's honestly significant difference (HSD) test by labelling bars with different lowercase letter $(a, b$, and $c)$. 
Mysore et al. [22] have examined the transcriptomic change in tomato upon 0 to 8 hpi of Pst and showed that the majority of defence-related transcriptional responses were significantly activated at $8 \mathrm{hpi}$. In addition, Parker et al. have examined the proteome change of tomato after 4 and $24 \mathrm{~h}$ inoculation of Pst using isobaric tags for relative and absolute quantitation (iTRAQ) approach and the 24 hpi of Pst was considered as the later time point for detecting the ETI responses [18]. In this study, in order to cover early to the later phases of the pathogenesis responses in protein level, 4, 8 and 24 hpi of Pst DC3000 were selected for the proteomics analysis. Three different pooled tryptic peptide samples, each combining Pst DC3000-inoculated and mock-treated samples from the same time point, were used in the data-dependent acquisition (DDA) method and results were searched from 3 different programs, Mascot, X!tandem and Comet, which were then merged to construct the spectral library. In total, 2174 proteins were identified by DIA analysis across the 3 time points of 4, 8 and $24 \mathrm{hpi}$ and the mock group, at 4, 8, $24 \mathrm{~h}$-post treatment (hpt). Of 1472 proteins being quantified in 3 biological replicates, 114, 147 and 337 proteins had a change in quantity between inoculation and mock at 4, 8, $24 \mathrm{~h}$ time points, respectively using the Student's t-test (Supplementary Tables S1 and S2). Among those, 20, 65 and 189 proteins had significant change in abundance with fold change greater than 1.5 or less than 0.67 at 4,8 and $24 \mathrm{hpi}$, respectively, compared to the mock $(p<0.05)$. Comparing to the previous protein quantitation results using iTRAQ approach, even though $>1.2$ - or $<$ 0.83 -fold change with $p$-value $<0.05$ was used to identify differentially expressed proteins, there were 128 tomato proteins found to be regulated at $24 \mathrm{hpi}$ of Pst DC3000 [18]. In this study, we identified 189 regulated proteins at 24 hpi using the protein fold change $>1.5$ or $<0.67$ with $p$-value $<0.05$ as the criteria. The higher number of regulated proteins identified in this study as compared to previous iTRAQ study at 24 hpi may possibly due to different experimental design or the ratio compression issue of the use of isobaric tagging proteomics approach.

The majority of proteins ( $90 \%)$ were identified in all 3 time points and only about 1 to $2 \%$ of the proteins were identified at one time point (Figure 2A). A similar situation was observed with the quantified proteins, most of which were shared between all the time points. However, there were no proteins with significant up- $(>1.5$-fold change) or down- $(<0.67$-fold change) regulation found at all the time points and only $\sim 8 \%$ of up-regulated or $\sim 24 \%$ of down-regulated proteins were shared between the 8 and $24 \mathrm{~h}$ time points. There were also more proteins with significant change, either up- or down-regulated, at 24 hpi than 8 or 4 hpi (Figure 2B), indicating that between 4,8 and 24 hpi, a different set of proteins were regulated in tomato leaves. More proteins showed a change in quantity at both 8 and 24 hpi, than between 4 and 24 or 4 and 8 hpi. 
A

(a)

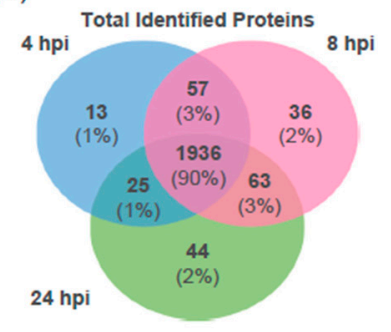

(c)

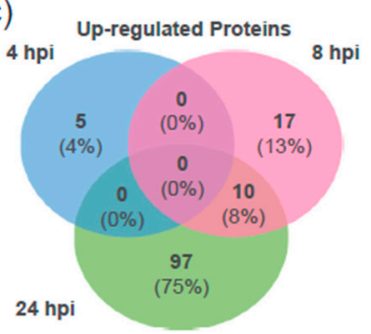

(b)

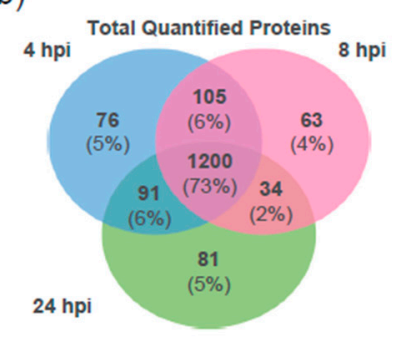

(d)

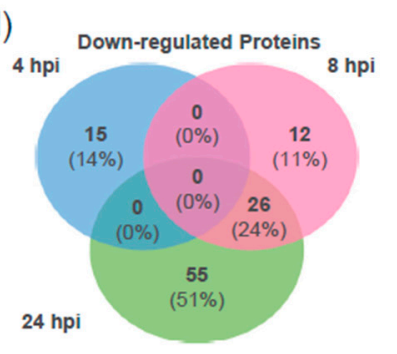

B

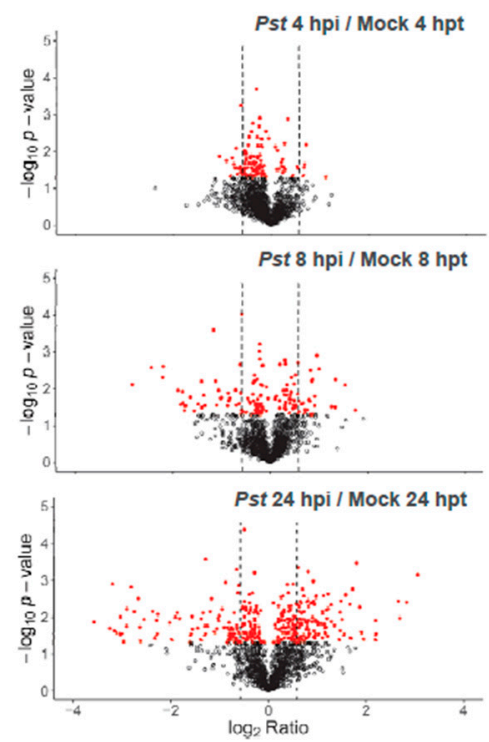

Figure 2. Proteomic change in tomato leaf between time points of Pst DC3000 inoculation 4, 8 or 24 hpi compared to each mock: 4, 8 or $24 \mathrm{hpt}$, respectively. (A) Venn diagrams showing unique and shared proteins between 3 time points which are (a) identified across replicates and (b) quantified in all 3 biological replicates or with significant increase, with fold change (c) greater than 1.5 or (d) less than 0.67 in quantity $(p<0.05)$, due to inoculation. (B) Volcano plots showing protein abundance ratio of Pst DC3000-inoculated over mock group at $4 \mathrm{hpi}, 8 \mathrm{hpi}$ and $24 \mathrm{hpi}$. Following LC-MS analysis and DIA quantification, $t$ test-based significance values $\left(\log _{10}\left(p\right.\right.$-value)) were plotted versus $\log _{2}$ (protein quantity ratio for all proteins between infected and mock). Differentially regulated proteins with $p<0.05$ are plotted in red. Proteins with $p>0.05$ are plotted in black. The level of protein abundance change with 1.5 or 0.67 -fold is marked by a dashed line. The data of quantified proteins in 3 biological replicates were listed in Supplementary Table 1 while the data of each replicate were listed in Supplementary Table 2.

\subsection{Functional Classification of the Proteins Regulated by Pst DC3000}

2.2.1. Function Categories of Proteins That are Significantly up- or down-Regulated during Pst DC3000 Inoculation

Because there are more thorough gene annotations in the Arabidopsis Information Resource (TAIR) database, using Protein Basic Local Alignment Search Tool (BLASTP), Arabidopsis homolog proteins were identified in TAIR from the tomato proteins that had a significant change between the inoculated and mock group. Regulated proteins with $>1.5$ or $<0.67$-fold change were categorized by protein function (Figure 3). More unique function categories were identified for the up-regulated proteins than the down-regulated proteins, including "response to other organism," "response to external stimulus," "response to biotic stimulus," "organic substance metabolic process," "multi-organism reproductive process," "immune response" and "developmental process involved in reproduction." This suggests that the proteins in these categories could be positive regulators in pathogen defence and immune responses. On the other hand, only one category, "response to endogenous stimulus," was identified in the down-regulated proteins. 


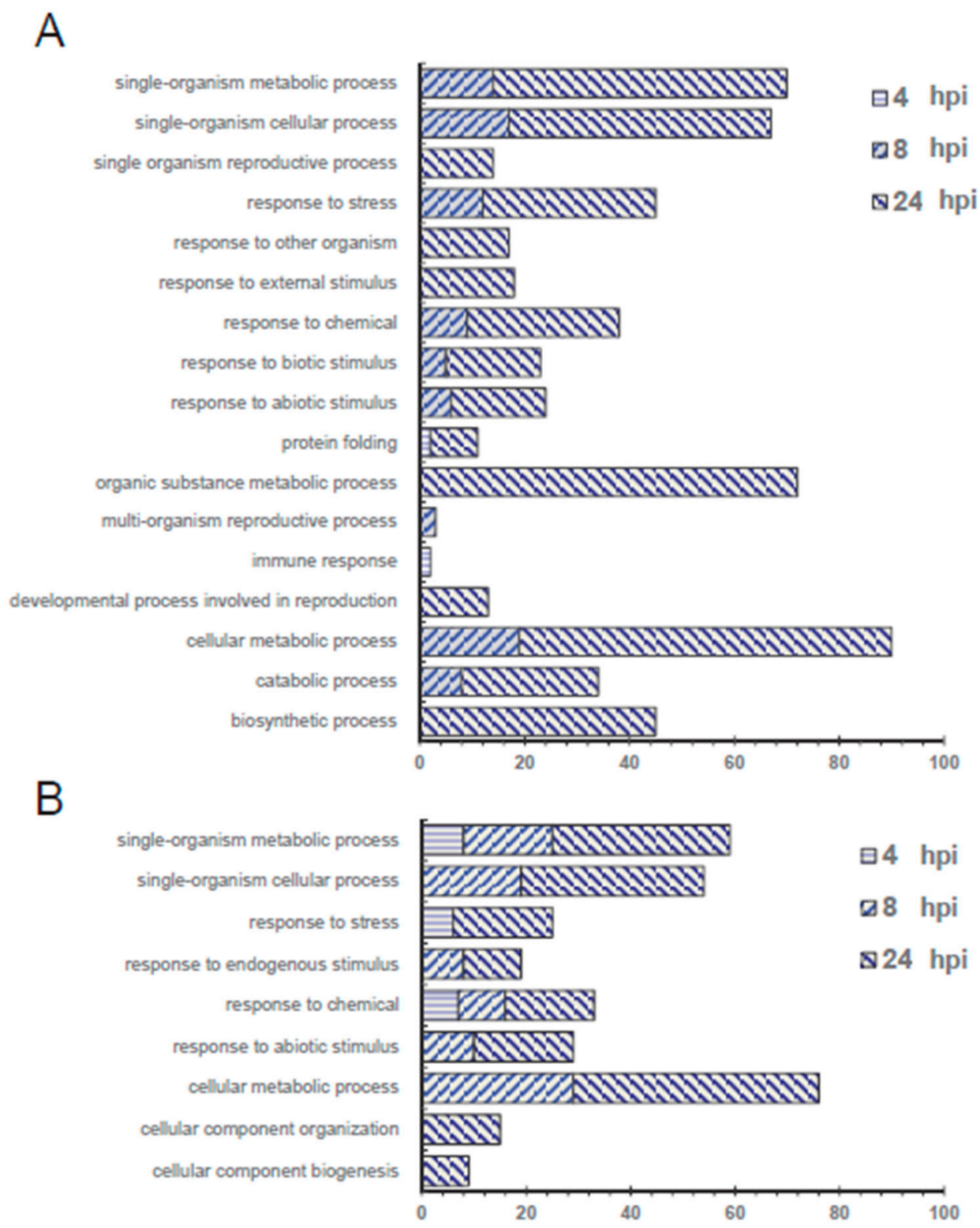

Figure 3. Biological process function analysis for tomato leaf proteins with a (A) significant increase or (B) decrease in quantity at different infection time points, 4, 8 or 24 hpi compared to the mock group. Only proteins with fold change greater than 1.5 or less than $0.67(p<0.05)$ were analysed and used for searching the Arabidopsis homolog proteins by Protein Basic Local Alignment Search Tool (BLASTP) against the Arabidopsis Information Resource (TAIR) database. Gene Ontology (GO) categorization of these Arabidopsis homolog proteins was performed by using the Database for Annotation, Visualization and Integrated Discovery (DAVID) v6.8.

\subsubsection{Proteins Related to the Key Mechanisms of Pathogenesis}

About 70 proteins with significant change in protein abundance upon Pst DC3000 inoculation across 4,8 and 24 hpi were selected and grouped with their protein function category (Tables 1-3). Table 1 summarizes the proteins involved in defence, immune response and ROS (reactive oxygen species)/redox metabolism. Proteins involved in these categories mostly were up-regulated at 8 and/or $24 \mathrm{hpi}$, except zeaxanthin epoxidase (ZEP; Solyc02g090890) and one peroxisome (Solyc09g072700). Interestingly, none of these were up-regulated at the early time point $4 \mathrm{hpi}$. Several pathogenesis-responsive proteins with known ROS/redox function were found to be differentially expressed in our results. However, these proteins did not show significant change 
in quantities in either the Pst-resistant (PtoR) or susceptible (Prf3) tomato genotypes at 4 hpi and $24 \mathrm{hpi}$ in the iTRAQ analysis [18], suggesting our findings could help researchers identify more protein candidates in response to pathogenesis. Table 2 summarizes proteins participating in protein translation, protein folding, degradation and transportation. Most proteins with function in translation and folding were up-regulated at 24 hpi. However, Heat shock proteins 90 (HSP90) and calnexin were the two early up-regulated proteins at $4 \mathrm{hpi}$. The protein product of Solyc04g080960, pre-pro-cysteine proteinase, also named as RD19A-like and DNA damage-inducible protein 1 (Solyc10g005890) were the ones with down-regulated protein level. DNA damage-inducible protein 1 belongs to a family of shuttle proteins targeting polyubiquitinated substrates for proteasomal degradation. Table 3 summarizes proteins involved in carbohydrate and energy metabolisms, including glycolysis/tricarboxylic acid (TCA) cycle, pentose phosphate pathway and carbon fixation (photosynthesis). Generally speaking, proteins involved in energy-generation, such as glycolysis and the TCA cycle, were up-regulated at 8 and $24 \mathrm{hpi}$; while proteins involved in photosynthesis and ATP synthesis were all down-regulated. Our data indicate that within the first $24 \mathrm{~h}$ of pathogenesis progression in plants, the plant required more energy for defence response and sacrificed the carbon fixation process. Table 4 summarizes proteins involved in oxidation phosphorylation, amino acid, fatty acid and secondary metabolisms like polyamine synthesis and shikimate pathway. Proteins grouped in amino acid metabolisms were up-regulated at $24 \mathrm{hpi}$ and the downstream compounds of these metabolic pathways are involved in the stress response, like polyamine, flavonoids and aromatic amino acid and phytohormones.

Table 1. Proteins involved in defence, immunity and ROS/redox mechanism with significant change in abundance at 4, 8, 24, hpi of Pst DC3000.

\begin{tabular}{|c|c|c|c|c|c|c|c|}
\hline \multirow{2}{*}{ Protein Description } & \multirow{2}{*}{$\begin{array}{l}\text { Gene } \\
\text { Accession }\end{array}$} & \multicolumn{2}{|c|}{4 hpi } & \multicolumn{2}{|c|}{8 hpi } & \multicolumn{2}{|c|}{24 hpi } \\
\hline & & $\begin{array}{c}\log _{2} \\
\text { Ratio }^{\text {a }}\end{array}$ & $p$-Value ${ }^{\text {b }}$ & $\begin{array}{c}\log _{2} \\
\text { Ratio }^{a}\end{array}$ & $p$-Value ${ }^{\mathrm{b}}$ & ${ }^{\log _{2}}$ Ratio $^{\text {a }}$ & $p$-Value ${ }^{\mathrm{b}}$ \\
\hline \multicolumn{8}{|l|}{ Defence } \\
\hline Pathogenesis-related protein 4 (PR-4) & Solyc01g097240 & -0.183 & 0.496 & 0.885 & 0.049 & NQ & NQ \\
\hline PIN-I protein (PR-6) & Solyc09g083440 & -0.023 & 0.971 & -1.163 & 0.052 & 1.484 & 0.004 \\
\hline Wound-induced proteinase inhibitor 1 & Solyc09g084465 & NQ & NQ & NQ & NQ & 1.183 & 0.019 \\
\hline Major allergen Pru ar 1 (PR-STH 2) & Solyc09g090970 & 0.239 & 0.038 & 0.827 & 0.003 & 1.106 & 0.036 \\
\hline Biotin-binding protein & Solyc09g065540 & 0.067 & 0.695 & 0.093 & 0.794 & 0.615 & 0.048 \\
\hline Chitinase Z15140 & Solyc10g055810 & -0.195 & 0.487 & 0.869 & 0.006 & 0.101 & 0.907 \\
\hline Beta-1,3-glucanase (PR-2) & Solyc01g008620 & 0.123 & 0.669 & 0.291 & 0.290 & 1.111 & 0.008 \\
\hline \multicolumn{8}{|l|}{ Immune Regulation } \\
\hline Pathogenesis-related protein 1 (PR-1) & Solyc00g174340 & -0.182 & 0.153 & 0.949 & 0.052 & 3.059 & 0.001 \\
\hline $\begin{array}{l}\text { 1-aminocyclopropane-1-carboxylate } \\
\text { oxidase } 1\end{array}$ & Solyc07g049530 & 0.132 & 0.705 & NQ & NQ & 2.831 & 0.004 \\
\hline Arginase 2 (ARG2) & Solyc01g091170 & 0.407 & 0.356 & 0.289 & 0.466 & 2.691 & 0.011 \\
\hline Cathepsin D Inhibitor & Solyc03g098780 & NQ & NQ & NQ & NQ & 1.947 & 0.040 \\
\hline Activator of $90 \mathrm{kDa}$ heat shock ATPase & Solyc10g078930 & 0.204 & 0.442 & 0.544 & 0.065 & 0.936 & 0.005 \\
\hline $\begin{array}{l}\text { FKBP-like peptidyl-prolyl cis-trans } \\
\text { isomerase family protein }\end{array}$ & Solyc09g008650 & 0.084 & 0.827 & 0.851 & 0.006 & 0.925 & 0.035 \\
\hline Kunitz trypsin inhibitor & Solyc03g098730 & -0.355 & 0.187 & NQ & NQ & 0.714 & 0.046 \\
\hline Zeaxanthin epoxidase (ZEP) & Solyc02g090890 & 0.112 & 0.353 & -0.799 & 0.067 & -0.711 & 0.047 \\
\hline \multicolumn{8}{|l|}{ ROS/Redox } \\
\hline Glutathione S-transferase/peroxidase & Solyc07g056480 & 0.041 & 0.814 & NQ & NQ & 1.870 & 0.005 \\
\hline Peroxidase & Solyc09g072700 & -0.345 & 0.089 & -0.500 & 0.336 & -0.814 & 0.029 \\
\hline Thioredoxin reductase & Solyc02g082250 & 0.064 & 0.930 & 0.813 & 0.022 & NQ & NQ \\
\hline Peroxidase & Solyc $04 \mathrm{~g} 071900$ & $\mathrm{NQ}$ & NQ & 0.906 & 0.016 & NQ & NQ \\
\hline Glutathione Reductase (GR) & Solyc09g091840 & 0.476 & 0.086 & 0.368 & 0.290 & 0.902 & 0.010 \\
\hline Glutathione S-transferase-like protein & Solyc09g011570 & 0.158 & 0.430 & 0.765 & 0.038 & 0.812 & 0.001 \\
\hline Glutathione S-transferase & Solyc06g009040 & 0.201 & 0.401 & 0.865 & 0.049 & 0.429 & 0.210 \\
\hline
\end{tabular}


Table 2. Proteins involved in translation, protein folding, degradation and transportation with significant change in abundance at 4, 8, 24, hpi of Pst DC3000.

\begin{tabular}{|c|c|c|c|c|c|c|c|}
\hline \multirow{2}{*}{ Protein Description } & \multirow{2}{*}{$\begin{array}{l}\text { Gene } \\
\text { Accession }\end{array}$} & \multicolumn{2}{|c|}{4 hpi } & \multicolumn{2}{|c|}{8 hpi } & \multicolumn{2}{|c|}{24 hpi } \\
\hline & & $\begin{array}{c}\log _{2} \\
\text { Ratio }^{\text {a }}\end{array}$ & $p$-Value $^{\mathrm{b}}$ & $\begin{array}{c}\log _{2} \\
\text { Ratio a }^{a}\end{array}$ & $p$-Value ${ }^{\mathrm{b}}$ & $\begin{array}{c}\log _{2} \\
\text { Ratio a }^{a}\end{array}$ & $p$-Value ${ }^{\mathrm{b}}$ \\
\hline \multicolumn{8}{|c|}{ Protein Translation, Folding, Degradation and Transportation } \\
\hline Protein transport protein sec 23 , putative & Solyc $05 \mathrm{~g} 053830$ & -0.023 & 0.894 & 0.262 & 0.271 & 1.012 & 0.016 \\
\hline Golgin candidate 6 & Solyc08g081410 & -0.087 & 0.655 & -0.095 & 0.612 & 0.680 & 0.040 \\
\hline Cathepsin B-like cysteine protease & Solyc02g069110 & NQ & NQ & NQ & NQ & 1.802 & 0.000 \\
\hline T-complex protein 1 subunit beta & Solyc11g069000 & -0.487 & 0.460 & 0.101 & 0.597 & 1.352 & 0.017 \\
\hline Pre-pro-cysteine proteinase & Solyc04g080960 & 0.313 & 0.193 & -0.634 & 0.025 & -0.388 & 0.316 \\
\hline Chaperonin 60 alpha subunit & Solyc06g075010 & -0.128 & 0.579 & -0.080 & 0.607 & 1.506 & 0.012 \\
\hline Heat shock $70 \mathrm{kDa}$ protein, putative & Solyc $07 \mathrm{~g} 043560$ & 0.233 & 0.194 & 0.251 & 0.298 & 1.223 & 0.002 \\
\hline Peptidyl-prolyl cis-trans isomerase & Solyc06g076970 & 0.211 & 0.697 & 0.759 & 0.500 & 1.212 & 0.033 \\
\hline Heat shock protein 90 & Solyc06g036290 & 1.140 & 0.050 & 1.475 & 0.109 & 0.841 & 0.050 \\
\hline Calnexin & Solyc03g 118040 & 0.672 & 0.028 & 0.256 & 0.576 & -0.067 & 0.881 \\
\hline
\end{tabular}

${ }^{\mathrm{a}}$ The average $\log _{2}$ ratio of protein quantity representing (inoculated/mock) from 3 biological replicates. ${ }^{\mathrm{b}} p$-value calculated from Student t-test. Color-coded: red, significant quantity change greater than 0.58 of $\log _{2}$ ratio; blue, significant quantity change less than -0.58 of $\log _{2}$ ratio; grey, no significant change between the inoculated and mock group ( $p \geq 0.05$ ); white, non-quantifiable (NQ).

Table 3. Proteins involved in carbohydrate and energy metabolisms with significant change in abundance at 4, 8, 24, hpi of Pst DC3000.

\begin{tabular}{|c|c|c|c|c|c|c|c|}
\hline \multirow{2}{*}{ Protein Description } & \multirow{2}{*}{$\begin{array}{l}\text { Gene } \\
\text { Accession }\end{array}$} & \multicolumn{2}{|c|}{4 hpi } & \multicolumn{2}{|c|}{$8 \mathrm{hpi}$} & \multicolumn{2}{|c|}{24 hpi } \\
\hline & & $\begin{array}{c}\log _{2} \\
\text { Ratio a }^{a}\end{array}$ & $p$-Value ${ }^{b}$ & $\begin{array}{c}\log _{2} \\
\text { Ratio a }^{a}\end{array}$ & $p$-Value ${ }^{\mathrm{b}}$ & $\begin{array}{c}\log _{2} \\
\text { Ratio a }^{\text {a }}\end{array}$ & $p$-Value ${ }^{b}$ \\
\hline \multicolumn{8}{|c|}{ Metabolism-Primary-Carbohydrate Metabolisms-Glycolysis \& TCA } \\
\hline Pyruvate kinase family protein & Solyc10g083720 & -0.104 & 0.326 & 0.316 & 0.208 & 0.915 & 0.001 \\
\hline Glyceraldehyde 3-phosphate dehydrogenase & Solyc $05 \mathrm{~g} 014470$ & 0.219 & 0.501 & 0.155 & 0.400 & 0.773 & 0.022 \\
\hline Glyceraldehyde-3-phosphate dehydrogenase & Solyc04g009030 & 0.258 & 0.027 & 0.196 & 0.208 & 0.663 & 0.004 \\
\hline \multicolumn{8}{|l|}{ Metabolism-Primary-Carbohydrate metabolism-PPP } \\
\hline 6-phosphogluconate dehydrogenase, decarboxylating & Solyc $04 \mathrm{~g} 005160$ & -0.372 & 0.392 & 0919 & 0.016 & 1.221 & 0.006 \\
\hline Transaldolase & Solyc00g006800 & -0.183 & 0.302 & 0.159 & 0.641 & 0.604 & 0.039 \\
\hline \multicolumn{8}{|l|}{ Metabolism-Primary-Carbon fixation } \\
\hline Photosystem II oxygen-evolving complex protein 3 & Solyc02g079950 & -0.739 & 0.057 & -0.694 & 0.028 & -0.250 & 0.157 \\
\hline Chlororespiratory reduction 31 & Solyc08g082400 & -0.529 & 0.136 & -1.402 & 0.033 & -1.397 & 0.042 \\
\hline ATP-dependent zinc metalloprotease FTSH protein & Solyc $07 \mathrm{~g} 055320$ & 0.118 & 0.646 & -1.340 & 0.029 & -2.270 & 0.008 \\
\hline \multicolumn{8}{|l|}{ Metabolism-Primary-Carbohydrate Metabolism-Others } \\
\hline Sucrose synthase & Solyc07g042550 & 0.250 & 0.297 & 1.200 & 0.031 & 1.542 & 0.031 \\
\hline Beta-fructofuranosidase & Solyc $04 \mathrm{~g} 081440$ & 0.261 & 0.367 & NQ & NQ & 0.818 & 0.005 \\
\hline xyloglucan endotransglucosylase-hydrolase 7 & Solyc02g091920 & 0.066 & 0.888 & 0.590 & 0.022 & 0.573 & 0.323 \\
\hline Starch synthase, chloroplastic/amyloplastic & Solyc03g083095 & -0.134 & 0.339 & -0.601 & 0.013 & -0.231 & 0.588 \\
\hline
\end{tabular}

${ }^{\mathrm{a}}$ The average $\log _{2}$ ratio of protein quantity representing (inoculated/mock) from 3 biological replicates. ${ }^{\mathrm{b}} p$-value calculated from Student t-test. Color-coded: red, significant quantity change greater than 0.58 of $\log _{2} \operatorname{ratio}_{\text {; blue, }}$ significant quantity change less than -0.58 of $\log _{2}$ ratio; grey, no significant change between the inoculated and mock group ( $p \geq 0.05)$; white, non-quantifiable (NQ).

Table 4. Protein involved in other primary and secondary metabolisms with significant change in abundance at 4, 8, 24, hpi of Pst DC3000.

\begin{tabular}{|c|c|c|c|c|c|c|c|}
\hline \multirow{2}{*}{ Protein Description } & \multirow{2}{*}{$\begin{array}{l}\text { Gene } \\
\text { Accession }\end{array}$} & \multicolumn{2}{|c|}{$4 \mathrm{hpi}$} & \multicolumn{2}{|c|}{$8 \mathrm{hpi}$} & \multicolumn{2}{|c|}{24 hpi } \\
\hline & & $\begin{array}{c}\log _{2} \\
\text { Ratio a }^{\text {a }}\end{array}$ & $p$-Value ${ }^{\mathrm{b}}$ & $\begin{array}{c}\log _{2} \\
\text { Ratio }^{\text {a }}\end{array}$ & $p$-Value ${ }^{\mathrm{b}}$ & $\begin{array}{c}\log _{2} \\
\text { Ratio a }^{\text {a }}\end{array}$ & $p$-Value ${ }^{\mathrm{b}}$ \\
\hline \multicolumn{8}{|l|}{ Metabolism-Primary-Oxidative phosphorylation } \\
\hline ATP synthase subunit alpha, chloroplastic & Solyc06g 072540 & -0.244 & 0.124 & -0.708 & 0.011 & -0.879 & 0.001 \\
\hline ATP synthase delta-subunit protein & Solyc12g056830 & -0.546 & 0.011 & -1.014 & 0.018 & -1.061 & 0.020 \\
\hline \multicolumn{8}{|c|}{ Metabolism-Primary-Amino Acid \& Polyamine Metabolism } \\
\hline S-adenosylmethionine synthase 2 (SAM2) & Solyc12g099000 & 0.045 & 0.924 & -0.345 & 0.564 & 1.194 & 0.006 \\
\hline Chorismate synthase 1 precursor & Solyc04g049350 & 0.151 & 0.259 & 0.335 & 0.072 & 0.830 & 0.030 \\
\hline S-adenosylmethionine synthase 1 (SAM1) & Solyc01g101060 & 0.224 & 0.091 & 0.190 & 0.034 & 0.681 & 0.012 \\
\hline S-adenosylmethionine synthase & Solyc10g083970 & NQ & NQ & NQ & NQ & 0.630 & 0.007 \\
\hline
\end{tabular}


Table 4. Cont.

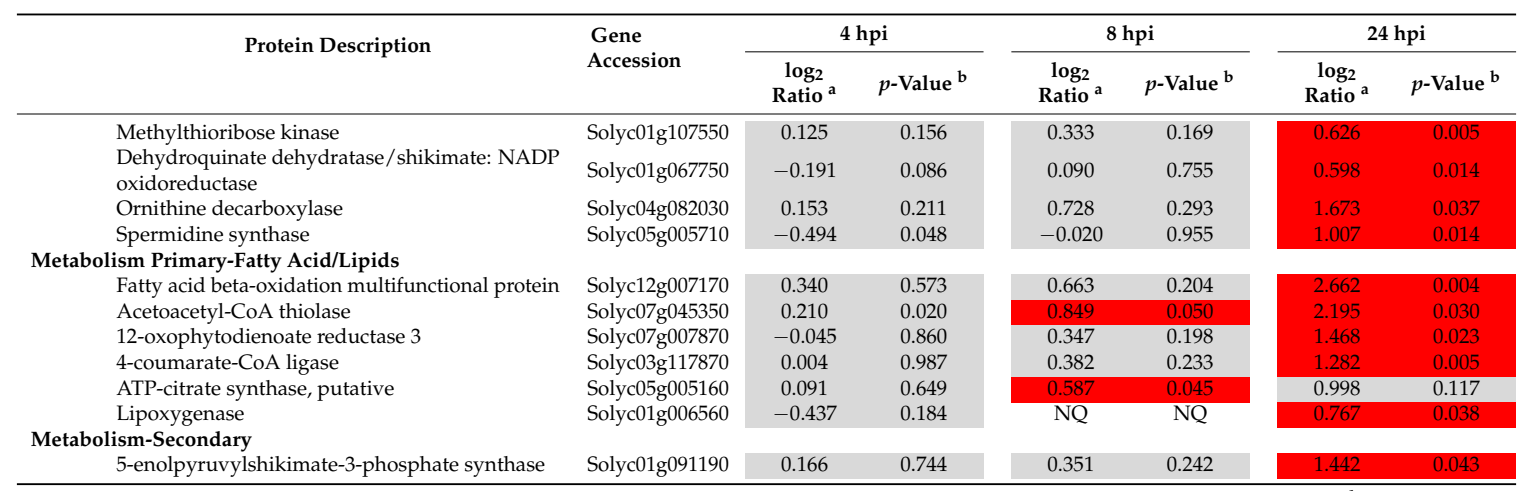

${ }^{\mathrm{a}}$ The average $\log _{2}$ ratio of protein quantity representing (inoculated/mock) from 3 biological replicates. ${ }^{\mathrm{b}} p$-value calculated from Student $t$-test. Color-coded: red, significant quantity change greater than 0.58 of $\log _{2}$ ratio; blue, significant quantity change less than -0.58 of $\log _{2}$ ratio; grey, no significant change between the inoculated and mock group $(p \geq 0.05)$; white, non-quantifiable (NQ).

\subsection{Changes Associated with Defence and Immune Regulation}

In this study, several proteins involved in the defence of pathogenesis were observed to be regulated mainly at 8 and 24 hpi. The two chitinases, pathogenesis-related protein 4 (PR-4) and chitinase Z15140 and major allergen Pru ar 1 (also known as Pathogenesis-Related Protein-STH 2-like; PR-STH 2-like) were found to be regulated at $8 \mathrm{hpi}$. Chitinases are enzymes catalysing the hydrolysis of chitin into $\mathrm{N}$-acetyl-D-glucosamine monomers therefore this enzyme can damage fungal cell walls and the exoskeleton of arthropods. PR- 4 was found to be induced not only by pathogen attack but also induced by ethylene in Arabidopsis [23,24]. Although PR-4 was classified as an endochitinase, its chitinase activity was found to be weak [25]. A more recent study indicated that PR-4 is a bifunctional enzyme with both RNase and DNase activity [26,27], which suggests that PR-4 may be involved in the regulation of HR. It was reported that the transient expression of PR- $4 \mathrm{~b}$ triggers hypersensitive cell death in Arabidopsis and the induction of PR4b is necessary to defend P. syringae and Hyaloperonospora arabidopsidis (Hpa) infection [28]. For major allergen Pru ar 1, this protein was also named as PR-10a and found to be induced after wounding, elicitor treatment or infection by Phytophthora infestans of the plants [29]. It has been shown that the parsley homologs of PR-10a are highly similar to a partial sequence of a ginseng ribonuclease [30], suggesting the protein encoded by the PR-10a domain could exhibit ribonuclease activity. Moreover, many of these genes have been shown to be controlled at the transcriptional level and to be expressed during the defence response or after wounding [24,31,32]. The function of the PR-10a protein is currently unknown.

At the later time point, $24 \mathrm{hpi}$, immune-related proteins, including the well-known SA-responsive marker genes/proteins, pathogenesis-related protein 1 (PR-1; Solyc00g174340), Kunitz trypsin inhibitor (KTI; Solyc03g098730) and arginase 2 (ARG2; Solyc01g091170) appeared to be dramatically up-regulated with up to 8-fold increase compared to the mock. PR-1 was observed to be highly up-regulated specifically at $24 \mathrm{hpi}$ with a fold change of $\sim 8.33$. PR- 1 is triggered by SA, a hormone in the deployment of systemic acquired resistance (SAR). SAR is the defence response occurring at the non-infected site (and thus called "systemic") to establish a long-term and broad-spectrum resistance throughout the entire plant after local pathogen infection is activated by avirulent pathogens [33]. Activation of the PR-1 gene requires the recruitment of a transcriptional enhanceosome to its promoter for which the SA receptor, Non-Expressor of Pathogenesis-Related Gene 1 (NPR1), is the key regulator [34]. Our previous study demonstrated the function of the PR-1 in the regulation of the immunity, in which PR-1 acts as a precursor for the signalling peptide CAPE1 to trigger defence responses regulated by methyl-jasmonic acid (MeJA) and SA [5]. We also demonstrated that the production of CAPE1 in tomato is regulated by the wounding response and MeJA may further enhance the production of this peptide elicitor [5]. This implies that the plant defence mechanism had started to significantly activate the SAR at $24 \mathrm{hpi}$. The wound- or JA-dependent responses during the later 
stage of pathogenesis response may further trigger CAPE1 to induce different sets of the defence responses. On the other hand, the protease KTI, which belongs to the Kunitz-type protease inhibitor (PI) whose serine protease activity specifically inhibits trypsin proteases which cleave polypeptides at the C-terminus of lysine and arginine, was up-regulated $\sim 1.64$-fold at $24 \mathrm{hpi}$ of Pst DC3000. The PI family are usually induced by JA-mediated response to wounding, pathogens or herbivore attack. The Arabidopsis homolog of Kunitz trypsin inhibitor, ARABIDOPSIS THALIANA KUNITZ TRYPSIN INHIBITOR 1 (AtKTI1), is a functional serine protease inhibitor that antagonizes pathogen-associated programmed cell death [35]. The gene expression of AtKTI1 is increased by 24 hpi of Pst DC3000 (especially with the effector avrB) in the microarray database [36] and also induced by $\mathrm{H}_{2} \mathrm{O}_{2}$, wounding, SA and some programmed cell death (PCD)-eliciting toxins from necrotrophic fungal pathogens. Since PCD, a cell-suicide act that needs to be tightly controlled for plant development and pathogen defence, it is speculated that plant induces KTI1 in the infected tissue in order to finely control the fate of plant cells under hemi-biotrophic pathogen inoculation. Previously researchers also found that AtKTI1 in plants can trigger both SA- and JA/ET-dependent defence gene expression, indicating the diverse role of this protein in defence responses including PTI and ETI [35]. In addition, another immune related protein ARG2 was observed to be $~ 6.5$-fold expressed when inoculated by Pst DC 3000 only at 24 hpi. ARG2 targets the mitochondria, hydrolyses the first step of arginine degradation to ornithine and urea, also provides the upstream production of proline, histidine and the polyamine biosynthetic pathway [37]. It has been found that the level protein expression and enzyme activity can be induced by wounding, JA treatment and Pst DC3000 phytotoxin coronatine in tomato [38]. In our study, ARG2 was severely up-regulated; however, in previously published research, the RNA level was induced as early as $1 \mathrm{hpi}$ and peaked at $8 \mathrm{hpi}$ [38]. This difference could be due to the difference between the different pathogen inoculation methods, as our method could avoid causing wounding compared to the traditional vacuum infiltration in the early stage of the treatment and thus delay the overexpression at the translational level. Besides polyamine, ARG2 may be involved in regulating nitric oxide (NO) accumulation. ARG2 has been shown to be important in the defence against necrotrophic pathogen Botrytis elliptica [39]. NO-mediated defence and immunity could be related to SA-JA antagonism as NO induces the accumulation of SA while inhibiting the expression of JA-responsive genes [40]. The late-induction level of ARG2 suggests that the HR-directed PCD by NO signalling could be triggered at $24 \mathrm{hpi}$.

\subsection{Changes Associated with the Reactive Oxygen Species (ROS) and Oxidation-Reduction Reactions}

ROS, including hydrogen peroxide $\left(\mathrm{H}_{2} \mathrm{O}_{2}\right)$ and superoxide $\left(\mathrm{O}_{2}{ }^{-}\right)$are involved in the early signalling for defence responses and also has direct toxicity against pathogen function, underlying PTI, ETI and SAR. The activity for mediating rapid accumulation of ROS during the oxidative burst is dependent on two classes of enzymes: NADPH oxidases and class III heme peroxidases [41,42]. NADPH oxidases synthesize the superoxide and peroxidases convert superoxide into a more stable form of ROS, $\mathrm{H}_{2} \mathrm{O}_{2}$. One peroxidase (Solyc04g071900) which belongs to the class III heme peroxidases was observed to be $\sim 1.8$-fold up-regulated at $8 \mathrm{hpi}$, suggesting a diverse ROS-related mechanism could be triggered at $8 \mathrm{hpi}$. Glutathione S-transferases (GSTs) are known for their function in anti-oxidative reactions to eliminate ROS and lipid hydroperoxides that accumulate in infected tissues thus limiting the excessive spread of HR- associated cell death [43]. Several GST family members have been shown to be PAMP-responsive genes in Arabidopsis [44]. In our study, the major antioxidant enzymes including several GSTs and GST-like proteins and glutathione reductase (GR) were up-regulated at 8 and/or 24 hpi upon Pst DC3000 inoculation.

In addition to glutathione and ascorbate, the most abundant antioxidant compounds in plant cells are oxidoreduction-active proteins called redoxins [45]. Thioredoxin ( $\operatorname{Trx})$ is a multigenic superfamily of ubiquitous redox proteins with multiple functions. Thioredoxin reductase (Solyc02g082250), one of ROS-detoxifying enzymes, was also up-regulated upon Pst DC3000 infection at 8 hpi, confirming that plants also trigger the redox change by thioredoxin reductase during pathogen inoculation. 
Although the up-regulation of plant GST proteins as a consequence of bacterium-induced oxidative stress was recognized as above mentioned, there were also some predicted peroxidases, GST proteins and ascorbate peroxidase (Table 1 \& Supplementary Table 1) were down-regulated at Pst DC3000 at $24 \mathrm{hpi}$. This is probably due to the effect of SA mediating ROS accumulation in cells by first promoting ROS accumulation (as these ROS are essential in the early defence response) and then inhibiting catalase and cytosolic ascorbate peroxidase, the main $\mathrm{H}_{2} \mathrm{O}_{2}$-detoxifying enzymes, to promote further accumulation of ROS which triggers the ETI response [37,46]. The effectiveness of SA-mediating defence response is also supported by our observation that between 4 and $24 \mathrm{hpi}$, the colony growth did not show significant change in our experiments (Figure 1B).

\subsection{Changes Associated with Protein Folding, Transportation and Degradation}

\subsubsection{Protein Folding: Heat Shock Proteins and Chaperones}

Heat shock proteins (HSPs) are a huge protein family participating in plant growth, development and fitness, mainly by helping mature protein folding or degrading mis-folded proteins. HSPs like HSP70, HSP90 and HSP60 belong to molecular chaperone families. Molecular chaperones bind and catalytically unfold misfolded and aggregated proteins as a primary cellular defensive and housekeeping function [47]. Plastidic chaperonin 60 (CPN60) alpha and beta are required for plastid division in Arabidopsis. CPN60 proteins are required to be maintained at a proper level for folding stromal plastid division proteins and are essential for the development of chloroplasts [48]. In our study, CPN60 alpha subunit (Solyc06g075010) was up-regulated by 2.8-fold, suggesting its important role in bacteria defence response.

The HSP90 family have been shown to be involved in regulating drought, salt and oxidative stress and involved in ATP-dependent assembly of the 26S proteasome [49]. We found that at Pst DC3000 4 hpi in tomato, HSP90 (Solyc06g036290) was induced 2.2-fold compared to the mock. It has been suggested that HSP90 protein could be an important helper to the regulation of the receptor proteins involved in plant immunity, nucleotide-binding site leucine-rich repeat (NB-LRR) type $R$ proteins. This interaction is apparently required for the NB-LRR type $R$ proteins to maintain the protein stability, especially their sensor signal-competent state [50]. HSP90 could physically interact with various R proteins, including RPM1 (RESISTANCE TO PSEUDOMONAS MACULICOLA 1), RPS2 (RESISTANCE TO P. SYRINGAE 2) and RPS4 (RESISTANCE TO PSEUDOMONAS SYRINGAE 4) in Arabidopsis [51,52]. In Nicotiana benthamiana, the complex formed by HSP90 and Suppressor of the G2 Allele of $s k p 1$ (SGT1) or Required for Mla12 Resistance 1 (RAR1) which is required for resistance gene Mla12 or both, is essential for plant survival against tobacco mosaic virus [53,54]. Our data showed that the quick induction of HSP90 at 4 hpi may function in improving the protein stability of NB-LRR, possibly by helping the protein folding, thus enhancing pathogen recognition and signal transduction.

\subsubsection{Protein Degradation}

The papain-like Cathepsin B-like cysteine protease (CathB), localized in the apoplast region, has proven to be a positive regulator of the HR defence [55]. One predicted gene product of Solyc02g069110, CathB protein, was dramatically increased in protein quantity at 24 hpi with $\sim 3.5$-fold. This protease family has endopeptidase activity at the C-terminus of the YVAD substrate and the enzyme activity was restricted predominately to acidic $\mathrm{pH}$ [56]. At $8 \mathrm{~h}$ of Pst DC3000 inoculation in tomato, Solyc04g080960 protein product, a cysteine protease (also known as Response to Dehydration 19A-like proteases; RD19A-like) was down-regulated with 0.64-fold change compared to mock treatment (Table 2). Liu and colleagues recently found that the expression level of Solyc04g080960 was reduced after $24 \mathrm{~h}$ of inoculation of the hemi-biotrophic pathogen Fusarium oxysporum $\mathrm{f}$. sp. lycopersici (FOL) in tomato [57]. On the other hand, RD19 protease activity is required for RPS1-R-dependent immune activation to enhance resistance against the necrotrophic pathogen Ralstonia solanacearum by 
being the interacting protein of R. solanacearum type III effector, Pseudomonas outer protein P2 (PopP2), thus initiating the downstream resistance response [58]. In Arabidopsis, AtRD19A also acts as an important protein marker for dehydration stress adaptation and could be highly induced by drought and salt stresses [59]. Taking our quantitative results into consideration, RD19A-like protein may be one of the responsive ends to the danger signals from necrotrophic pathogen attack and abiotic stress like drought or salt stress. Therefore, during the infection of Pst DC3000, plants could down-regulate RD19A-like protein in order to be more cost-effective in defence response.

\subsection{Changes Associated with Phytohormone Synthesis and Fatty Acid Metabolism}

In our data, Zeaxanthin epoxidase (ZEP; Solyc02g090890), participating in the biosynthetic pathway upstream of ABA (abscisic acid), was down-regulated at 24 hpi by $\sim 0.61$-fold (Table 1 ). This kind of down-regulation could be the result of the antagonism between ABA and SA [60], since the phytohormone SA is induced by diverse biotrophic/hemi-biotrophic pathogens to activate SAR responses [54].

It has been long believed that there is also antagonism between SA and JA, including the control of each one's biosynthetic pathway. In our data, several proteins possibly involved upstream of the JA-biosynthetic pathway have been identified, such as fatty acid beta-oxidation multifunctional protein (Absent In Melanoma 1-like; AIM1-like; Solyc12g007170) which showed a 6.3-fold increase at $24 \mathrm{hpi}$ and lipoxygenase (Solyc01g006560) with $\sim 1.7$-fold increase at $24 \mathrm{hpi}$. The results of $24 \mathrm{~h}$-time point suggest that the JA/ET-mediated defence response could be induced. Our results showed the ET biosynthetic enzyme, 1-aminocyclopropane-1-carboxylate oxidase 1 (ACO; Solyc07g049530) was dramatically up-regulated at the $24 \mathrm{~h}$-time point by $\sim 7$-fold. Several S-adenosylmethionine synthase family proteins were also up-regulated by $\sim 2.3$-fold at $24 \mathrm{hpi}$ and they are involved in the shikimic acid pathway, which is the upstream of ET and polyamine biosynthesis, suggesting the level of ET should be hugely increased at this late time point.

\section{Materials and Methods}

\subsection{Plant Materials and Growth Condition}

Tomato seeds (Solanum lycopersicum cv CL5915, originally provided by AVRDC-The World Vegetable Centre at Tainan, Taiwan) were germinated in soil and grown in a growth chamber for $4-5$ weeks. The growth chamber condition was set as $25^{\circ} \mathrm{C} / 22{ }^{\circ} \mathrm{C}$ (day/night) temperature, $50 \% / 70 \%$ (day $/$ night) humidity and $16 \mathrm{~h} / 8 \mathrm{~h}$ (day /night) photoperiod using the light source providing photosynthetic photon flux density (PPFD) $80 \mu \mathrm{mole} / \mathrm{m}^{2} \cdot \mathrm{s}$. Leaflets with similar size from the $3 \mathrm{rd}$ to 5 th pair of true leaves were collected for the following inoculation experiment.

\subsection{Pseudomonas Preparation and Inoculation Assays}

Pst DC3000 from B. N. Kunkel (Washington University, St. Louis, MO, USA) [61] was used as a pathogenic strain on tomato plants. The growth and isolation method were referred to the work published by Desclos-Theveniau et al. [62]. The dipping inoculation method for detached leaf is adapted from previous studies [18,63]. Pst DC3000 was grown overnight in liquid King's B medium [64] with $50 \mu \mathrm{g} / \mathrm{mL}$ rifampicin at $28{ }^{\circ} \mathrm{C}$ then resuspended in $10 \mathrm{mM} \mathrm{MgSO}$ and $P_{s t} \mathrm{DC} 000$ suspension was adjusted to $\mathrm{OD}_{600}$ of $0.02\left(\sim 10^{7} \mathrm{cfu} / \mathrm{mL}\right)$. The detached leaves from tomato plants were dipped in Pst DC3000 suspension solution with $0.005 \%$ Silwet L-77 for $2 \mathrm{~min}$ and then placed on water-saturated paper in a petri dish. The dishes were covered and incubated in the growth chamber. The control inoculum as the mock group contained the same components as the bacteria inoculum but without Pst DC3000. Disease symptoms and bacterial population were evaluated 0, 4, 8, $24 \mathrm{~h}$ and 3, 5, 7 days after inoculation. To estimate the internal bacterial population, leaves were surface sterilized with $70 \%$ ethanol, washed twice with sterile distilled water and then homogenized in $10 \mathrm{mM}$ $\mathrm{MgSO}_{4}$. The solution was diluted and spotted onto the King's B agar medium [64] with $50 \mu \mathrm{g} / \mathrm{mL}$ 
rifampicin. Colonies were counted and reported as means and standard deviations of results for three biological replicates.

\subsection{Sample Preparation: Protein Extraction and Digestion}

Three biological replicates of mock-treated (4, 8, $24 \mathrm{hpt})$ and Pst DC3000 inoculated (4, 8, $24 \mathrm{hpi})$ leaves were prepared for the proteomics experiments. For each sample, leaves were ground into powder in the chilled mortar and pestle with liquid $\mathrm{N}_{2}$ then $0.5 \mathrm{~g}$ of powder was collected. The sample was then homogenized with $2.5 \mathrm{~mL}$ of ice-cold homogenization buffer (50 mM HEPES-KOH, pH 7.5, $250 \mathrm{mM}$ sucrose, $5 \%$ glycerol stock, $10 \mathrm{mM}$ EDTA, $\mathrm{pH}$ 8.0, 0.5\% Soluble polyvinylpyrrolidone (PVP-10), $3 \mathrm{mM}$ dithiothreitol, $1 \mathrm{mM}$ phenylmethylsulfonyl fluoride and $1 \times$ protease inhibitor cocktail) by vortexing for at least $3 \mathrm{~min}$ or until completely homogenized. The sample was further incubated in the buffer by Intelli Mixer RM-2L (ELMI Ltd., Riga, Latvia) in the cold room for $30 \mathrm{~min}$. The homogenate was filtered through two layers of miracloth. The volume of filtrate should be relatively close to the initial amount of added homogenization buffer. The supernatant of the filtrate was then collected by centrifugation at $15,000 \times g$ for 10 min under $4{ }^{\circ} \mathrm{C}$. The protein concentration of each sample was measured by the Bradford assay to quantify the protein amount of total protein.

For each sample, $100 \mu \mathrm{g}$ of the total protein was precipitated by addition of acetone to $80 \%$ with incubation at $-20^{\circ} \mathrm{C}$ overnight and recovered by centrifugation at $16,000 \times g$ for 15 min under $4{ }^{\circ} \mathrm{C}$. The reduction and alkylation steps were adapted from the literature as previously described [65]. Re-solubilized proteins were reduced in $50 \mathrm{mM}$ ammonium bicarbonate (ABC) buffer and $8 \mathrm{M}$ urea with $5 \mathrm{mM}$ tris(2-carboxyethyl)phosphine hydrochloride (TCEP) for $1 \mathrm{~h}$ at $37^{\circ} \mathrm{C}$ and alkylated using $20 \mathrm{mM}$ iodoacetamide for $45 \mathrm{~min}$ in the dark at room temperature. Each sample was diluted 4-fold using $50 \mathrm{mM} \mathrm{ABC}$ to decrease the urea concentration to less than $2 \mathrm{M}$ then digested with lysyl endopeptidase (LysC; Wako Chemicals, Japan) to a final ratio of 1:50 at room temperature for $3 \mathrm{~h}$. Next the sample was diluted using $50 \mathrm{mM} \mathrm{ABC}$ to decrease the urea concentration to $\sim 1 \mathrm{M}$ before digestion with sequencing grade trypsin (Promega, Madison, WI, USA) to a final ratio of 1:50. The proteolysis was continued overnight $(14 \mathrm{~h})$ at room temperature and terminated by addition of formic acid to a final concentration of $1 \%$ (vol/vol). The digest sample was then desalted using the 50-mg tC18 SepPak cartridge (Waters Corporation, Milford, MA, USA) as described previously [66]. The tryptic peptides from individual sample was dissolved by deionized water containing $2 \%$ acetonitrile and $0.1 \%(\mathrm{v} / \mathrm{v})$ formic acid to the concentration of $500 \mathrm{ng} / \mu \mathrm{L}$. Three different pooled tryptic peptide samples for DDA analyses in order to construct the DIA spectral library were prepared by combining $4 \mu \mathrm{g}$ peptides from the same time point of Pst DC3000-inoculated and mock-treated sample. For the purpose of retention time calibration, the iRT-standard peptides (Biognosys, Schlieren, Switzerland) were added into the pooled sample and also each individual sample at $1 / 10$ by volume.

\subsection{Liquid Chromatography-Mass Spectrometry Analysis}

The nanoLC-MS/MS was equipped with a self-packed tunnel-frit [67] analytical column (ID $75 \mu \mathrm{m} \times 50 \mathrm{~cm}$ length) packed with ReproSil-Pur 120A C18-AQ $1.9 \mu \mathrm{m}$ (Dr. Maisch GmbH, Ammerbuch-Entringen, Germany) at $40^{\circ} \mathrm{C}$ on a nanoACQUITY UPLC System (Waters Corporation, Milford, MA, USA) connected to a Q Exactive HF Hybrid Quadrupole-Orbitrap mass spectrometer (Thermo Scientific, Bellefonte, PA, USA). The peptides were separated by a 135-min gradient using the mobile phases including Solvent A $(0.1 \%(v / v)$ formic acid) and Solvent B (acetonitrile with $0.1 \%$ formic acid). With a flow rate of $250 \mathrm{~nL} / \mathrm{min}$, the gradient started with a 40 min equilibration maintained at $2 \%$ of B and set as the following segments: 2 to $8 \%$ of B in $8 \mathrm{~min}, 8$ to $25 \%$ of B in $90 \mathrm{~min}$, then $25 \%$ to $48 \%$ of $\mathrm{B}$ in $5 \mathrm{~min}, 48$ to $80 \%$ of $\mathrm{B}$ in another $5 \mathrm{~min}$ followed by $80 \%$ of $\mathrm{B}$ wash $10 \mathrm{~min}$ and the last equilibrium to $2 \% \mathrm{~B}$ in the last $20 \mathrm{~min}$.

The instrumentation and parameters for DDA and DIA analysis were referred to the previous studies using Q Exactive HF Hybrid Quadrupole-Orbitrap mass spectrometer $[68,69]$. Two micrograms of the pooled and individual tryptic peptide samples were analysed by DDA and DIA mode, 
respectively. For DDA analysis, the MS instrument was operated in the positive ion mode and DDA methods for detection of proteome. The instrument was configured to collect high resolution $(R=60,000$ at $m / z 200$ at an automatic gain control target of $\left.3.0 \times 10^{6}\right)$ broadband mass spectra $(m / z 350-1650 \mathrm{Da})$ with a maximum IT of $20 \mathrm{~ms}$ and MS/MS events $(R=15,000$ at an automatic gain control target of $1.0 \times 10^{5}$ ) with a dd-MS ${ }^{2}$ IT of $25 \mathrm{~ms}$ when a precursor ion charge was $2+, 3+, 4+$ and $5+$ and an intensity greater than $1.0 \times 10^{4}$, isolation window was set to $1.6 \mathrm{~m} / \mathrm{z}$, was detected. The 15 most abundant peptide molecular ions, dynamically determined from the MS1 scan, were selected for MS/MS using a relative higher energy collisional dissociation (HCD) energy of $28 \%$ with the dynamic exclusion was $35 \mathrm{~s}$. For DIA analysis, MS/MS proteome profiling, was analysed by the same LC-MS/MS system. The instrument was operated in the positive ion mode and configured to collect high resolution $\left(R=120,000\right.$ at $m / z 200$ at an automatic gain control target of $\left.3.0 \times 10^{6}\right)$ broadband mass spectra $(\mathrm{m} / \mathrm{z} 350-1650 \mathrm{Da})$ with a maximum IT of $60 \mathrm{~ms}$ and MS/MS events $(R=30,000$ at an automatic gain control target of $3.0 \times 10^{6}$ ) with an auto MS ${ }^{2}$ IT, isolation window was set to $52.0 \mathrm{~m} / \mathrm{z}$, fixed first mass was set to $200 \mathrm{~m} / z$. The 25 segments were selected for MS/MS using a relative higher energy collisional dissociation (HCD) energy of $28 \%$. The acquisition window covered a mass range from 350 to $1650 \mathrm{~m} / \mathrm{z}$ through 25 consecutive isolation windows.

\subsection{Data Analysis for LC-MS}

With the DDA data files, the Mascot (ver. 2.3, http:/ /www.matrixscience.com/), X!Tandem (ver. 2013.06.15.1) [70] and Comet (ver. 2017.01 rev.1) [71] were used to do a protein database search against a combined database of ITAG (ver. 3.1, https://solgenomics.net/organism/ Solanumlycopersicum/genome; 34881 entries reverse sequence generate as the decoy database) and the iRT standard peptides and BSA (SwissProt Accession: P02769) sequence. Search parameters were set as follows: MS tolerance, $20 \mathrm{ppm}$, allow precursor monoisotopic mass isotope error; number of trypsin missed cleavage: 2; Fragment Mass tolerance, 0.2 Da; enzyme, trypsin; static modifications, carbamidomethyl (Cys, + 57.021 Da); dynamic modifications, oxidation (+15.995 Da) of methionine. Next the software on the Trans-Proteomic Pipeline (TPP, ver. 5.1) [72] was used to combine the search result from different search engines and different repeats; there were a total 116,422 peptide-spectrum matches. In the constructed library, there were a total 67,536 transitions, 9343 peptides and 3070 proteins.

OpenMS (ver. 2.2.0) [73] was utilized for decoyed spectral library construction. We employed the OpenSWATH (ver. 0.1.2) [74] to search the DIA files against the spectral library we constructed. The retention time alignment used the information of iRT transitions. In addition to the chromatogram alignment, the spike-in iRT peptide standards were also used for the quality control of the DDA and DIA analyses. In all DDA and DIA analyses across the sequence of the instrument in the study, the coefficient of variation (CV) of iRT peptide retention time should be less than $3 \%$ and the $\mathrm{CV}$ of iRT peptide peak intensity should be less than $20 \%$. Search parameters were set as follows: peptide false-discovery rate (FDR), 0.05; protein FDR, 0.01; alignment method, LocalMST; re-alignment method, lowest; retention time (RT) difference, 60; alignment score, 0.05 . The ratios of protein quantitation between the Pst DC3000-inoculated and mock-treated sample in each replicate were normalized by the most-likely ration normalization principle as previously applied in the DIA study [75].

\subsection{Quantitation Data Analysis}

Only proteins detected and quantified in all runs (3 biological replicates) were included in the data set. To perform a significance test, the students' t-test was calculated. Any protein with differential abundance with a $p$-value of less than 0.05 and fold change greater than 1.5 or less than 0.67 was defined as being "significantly" regulated in protein quantity. Functional annotations of the quantified tomato proteins were obtained via PANTHERN (ver. 13.1) [76,77]. To show the functional distribution of the regulated proteins, the up- and down-regulated protein sequences were searched against the Arabidopsis thaliana TAIR10 database (http://arabidopsis.org) using 
BLASTP with E-value $<1.0 \times 10^{-5}$ (https:/ /blast.ncbi.nlm.nih.gov/Blast.cgi) first and the matched Arabidopsis homolog proteins were categorized by the GO biological function level 2 using DAVID v6.8 (https://david.ncifcrf.gov/) [78,79].

\section{Conclusions}

This study demonstrated a successful example of using the DIA approach for a time course analysis of plant pathogenesis proteomics. A total of $\sim 2200$ proteins were identified and quantified from the tomato subjected to different treatments and $90 \%$ of the totally identified proteins were commonly observed across all the treatments. This study indicates different sets of proteins are regulated from the early to the later stage of the Pst DC3000 infection. We showed that no defence-related protein was observed to be up-regulated but the chaperone proteins for helping the activity of $\mathrm{R}$ proteins was induced at $4 \mathrm{hpi}$ of Pst DC3000. Several major defence and immune-related proteins were found to be up-regulated at 8 and 24 hpi. One of the peroxidase proteins related to the production of $\mathrm{H}_{2} \mathrm{O}_{2}$ was up-regulated at $8 \mathrm{hpi}$. We have shown that plants do not only express proteins for accumulating $\mathrm{H}_{2} \mathrm{O}_{2}$ but also detoxification proteins to avoid the over-accumulation of ROS. The proteins involved in the later stage of the pathogenesis which are related to the HR and PCD were up-regulated at $24 \mathrm{hpi}$. We also discovered that the proteins involved in the biosynthesis of JA and ET were induced at $24 \mathrm{hpi}$, indicating ET/JA may be induced in the later pathogenesis response. More time points and treatments can be further analysed and compared with the current DIA datasets based on the library established in this study. The number of proteins identified and quantified with the use of the current DIA approach can also be increased when a more comprehensive spectra library for the tomato proteome is established.

Supplementary Materials: Supplementary materials can be found at http:/ / www.mdpi.com/1422-0067/20/ 4/863/s1. Supplemental Figure S1, disease phenotypes and population dynamics of Pseudomonas syringae pv. tomato on the tomato leaves at $24 \mathrm{hpi}, 3 \mathrm{dip}$ and $7 \mathrm{dpi}$. Supplemental Table 1, list of quantified proteins with significant change in abundance at $4 \mathrm{hpi}, 8 \mathrm{hpi}$ or $24 \mathrm{hpi}$ compared to mock. Supplemental Table 2, full list of quantified proteins and peptides in three biological replicates of the Pst DC3000-inoculated (4 hpi, 8 hpi, 24 hpi) and mock-treated ( $4 \mathrm{hpt}, 8 \mathrm{hpt}$ and $24 \mathrm{hpt}$ ) experiments. All the mass spectrometry raw data files were deposited to the ProteomeXchange Consortium via the PRIDE [80] partner repository with the dataset identifier PXD012226.

Author Contributions: Conceptualization, K.-T.F. and Y.-R.C.; Data curation, W.-H.C.; Funding acquisition, Y.-R.C.; Methodology, K.-T.F., K.-H.W., C.-F.Y., K.-T.C. and S.-C.H.; Project administration, Y.-R.C.; Resources, Y.-R.C.; Software, W.-H.C. and J.-C.Y.; Supervision, Y.-R.C.; Visualization, K.-T.F., K.-H.W. and S.-C.H.; Writing-original draft, K.-T.F., S.-C.H. and Y.-R.C.; Writing-review \& editing, K.-T.F., S.-C.H. and Y.-R.C.

Funding: This work was financially supported by the Ministry of Science and Technology, Taiwan (Project number 107-2113-M-001-006-); Academia Sinica, Taiwan (Project number 105-L03); Innovative Translational Agricultural Research Program, Taiwan (Project ID AS-KPQ-108-ITAR-07).

Acknowledgments: The MS analysis was supported by the Metabolomics Facilities of the Scientific Instrument Center at Academia Sinica. We thank Chia-Wei Hsu for helping monitor the quality of LC-MS data acquisition.

Conflicts of Interest: The authors declare no conflict of interest. The funders had no role in the design of the study; in the collection, analyses or interpretation of data; in the writing of the manuscript or in the decision to publish the results.

\section{Abbreviations}

$\begin{array}{ll}\text { DIA } & \text { data-independent acquisition } \\ \text { DDA } & \text { data-dependent acquisition } \\ \text { PAMP } & \text { pathogen-associated molecular pattern } \\ \text { MAMP } & \text { microbial associated molecular pattern } \\ \text { DAMP } & \text { damaged-associated molecular pattern } \\ \text { ETS } & \text { effector-triggered susceptibility } \\ \text { PTI } & \text { PAMP-triggered immunity }\end{array}$




$\begin{array}{ll}\text { ETI } & \text { effector-triggered immunity } \\ \text { HR } & \text { hypersensitive response } \\ \text { PCD } & \text { programmed cell death } \\ \text { SA } & \text { salicylic acid } \\ \text { JA } & \text { jasmonic acid } \\ \text { ABA } & \text { abscisic acid } \\ \text { ET } & \text { ethylene } \\ \text { Pst DC3000 } & \text { Pseudomonas syringae pv. tomato DC3000 } \\ \text { SAR } & \text { systemic acquired resistance }\end{array}$

\section{References}

1. Underwood, W. The Plant Cell Wall: A Dynamic Barrier against Pathogen Invasion. Front. Plant Sci. 2012, 3, 1-6. [CrossRef]

2. Takai, R.; Isogai, A.; Takayama, S.; Che, F.-S. Analysis of Flagellin Perception Mediated by Flg22 Receptor Osfls2 in Rice. Mol. Plant-Microbe Interact. 2008, 21, 1635-1642. [CrossRef]

3. Pearce, G.; Strydom, D.; Johnson, S.; Ryan, C.A. A Polypeptide from Tomato Leaves Induces Wound-Inducible Proteinase Inhibitor Proteins. Science 1991, 253, 895-897. [CrossRef]

4. Huffaker, A.; Pearce, G.; Ryan, C.A. An Endogenous Peptide Signal in Arabidopsis Activates Components of the Innate Immune Response. Proc. Natl. Acad. Sci. USA 2006, 103, 10098-10103. [CrossRef]

5. Chen, Y.-L.; Lee, C.-Y.; Cheng, K.-T.; Chang, W.-H.; Huang, R.-N.; Nam, H.G.; Chen, Y.-R. Quantitative Peptidomics Study Reveals That a Wound-Induced Peptide from PR-1 Regulates Immune Signaling in Tomato. Plant Cell 2014, 26, 4135-4148. [CrossRef]

6. Tanaka, K.; Choi, J.; Cao, Y.; Stacey, G. Extracellular Atp Acts as a Damage-Associated Molecular Pattern (DAMP) Signal in Plants. Front. Plant Sci. 2014, 5, 1-9. [CrossRef]

7. Choi, H.W.; Klessig, D.F. Damps, Mamps and Namps in Plant Innate Immunity. BMC Plant Biol. 2016, 16, 1-10. [CrossRef]

8. Peng, Y.; Wersch, R.V.; Zhang, Y. Convergent and Divergent Signaling in PAMP-Triggered Immunity and Effector-Triggered Immunity. Mol. Plant Microbe Interact. 2018, 31, 403-409. [CrossRef]

9. Dangl, J.L. Pivoting the Plant Immune System from Dissection to Deployment. Science 2013, 341, 745-751. [CrossRef]

10. Jones, J.D.G.; Dangl, J.L. The Plant Immune System. Nature 2006, 444, 323-329. [CrossRef]

11. Tao, Y.; Xie, Z.; Chen, W.; Glazebrook, J.; Chang, H.-S.; Han, B.; Zhu, T.; Zou, G.; Katagiri, F. Quantitative Nature of Arabidopsis Responses during Compatible and Incompatible Interactions with the Bacterial Pathogen Pseudomonas syringae. Plant Cell Online 2003, 15, 317-330. [CrossRef]

12. Navarro, L.; Zipfel, C.; Rowland, O.; Keller, I.; Robatzek, S.; Boller, T.; Jones, J.D.G. The Transcriptional Innate Immune Response to Flg22. Interplay and Overlap with Avr Gene-Dependent Defense Responses and Bacterial Pathogenesis. Plant Physiol. 2004, 135, 1113-1128. [CrossRef]

13. Mukhtar, M.S.; McCormack, M.E.; Argueso, C.T.; Pajerowska-Mukhtar, K.M. Pathogen Tactics to Manipulate Plant Cell Death. Curr. Biol. 2016, 26, R608-R619. [CrossRef]

14. Kim, Y.; Tsuda, K.; Igarashi, D.; Hillmer, R.A.; Sakakibara, H.; Myers, C.L.; Katagiri, F. Mechanisms Underlying Robustness and Tunability in a Plant Immune Signaling Network. Cell Host Microbe 2014, 15, 84-94. [CrossRef]

15. Bozso, Z.; Ott, P.G.; Kaman-Toth, E.; Bognar, G.F.; Pogany, M.; Szatmari, A. Overlapping yet Response-Specific Transcriptome Alterations Characterize the Nature of Tobacco-Pseudomonas syringae Interactions. Front. Plant Sci. 2016, 7, 251. [CrossRef]

16. Tsuda, K.; Sato, M.; Stoddard, T.; Glazebrook, J.; Katagiri, F. Network Properties of Robust Immunity in Plants. PLoS Genet. 2009, 5, e1000772. [CrossRef]

17. Moore, J.; Penfold, C.A.; Jenkins, D.J.; Hill, C.; Baxter, L.; Kulasekaran, S.; Truman, W.; Littlejohn, G.; Prusinska, J.; Mead, A.; et al. Transcriptional Dynamics Driving MAMP-Triggered Immunity and Pathogen Effector-Mediated Immunosuppression in Arabidopsis Leaves Following Infection with Pseudomonas syringae pv. tomato DC3000. Plant Cell 2015, 27, 3038-3064. 
18. Parker, J.; Koh, J.; Yoo, M.J.; Zhu, N.; Feole, M.; Yi, S.; Chen, S. Quantitative Proteomics of Tomato Defense against Pseudomonas syringae Infection. Proteomics 2013, 13, 1934-1946. [CrossRef]

19. Ow, S.Y.; Salim, M.; Noirel, J.; Evans, C.; Wright, P.C. Minimising Itraq Ratio Compression through Understanding LC-MS Elution Dependence and High-Resolution Hilic Fractionation. Proteomics 2011, 11, 2341-2346. [CrossRef]

20. Gillet, L.C.; Navarro, P.; Tate, S.; Röst, H.; Selevsek, N.; Reiter, L.; Bonner, R.; Aebersold, R. Targeted Data Extraction of the MS/MS Spectra Generated by Data-Independent Acquisition: A New Concept for Consistent and Accurate Proteome Analysis. Mol. Cell. Proteom. 2012, 11, O111.016717. [CrossRef]

21. Xin, X.F.; Kvitko, B.; He, S.Y. Pseudomonas syringae: What It Takes to Be a Pathogen. Nat. Rev. Microbiol. 2018, 16, 316-328. [CrossRef]

22. Mysore, K.S.; Crasta, O.R.; Tuori, R.P.; Folkerts, O.; Swirsky, P.B.; Martin, G.B. Comprehensive Transcript Profiling of Pto- and Prf-Mediated Host Defense Responses to Infection by Pseudomonas syringae pv. tomato. Plant J. 2002, 32, 299-315. [CrossRef]

23. Midoh, N.; Iwata, M. Cloning and Characterization of a Probenazole-Inducible Gene for an Intracellular Pathogenesis-Related Protein in Rice. Plant Cell Physiol. 1996, 37, 9-18. [CrossRef]

24. Somssich, I.E.; Schmelzer, E.; Kawalleck, P.; Hahlbrock, K. Gene Structure and in Situ Transcript Localization of Pathogenesis-Related Protein 1 in Parsley. Mol. Gen. Genet. 1988, 213, 93-98. [CrossRef]

25. Brunner, F.; Stintzi, A.; Fritig, B.; Legrand, M. Substrate Specificities of Tobacco Chitinases. Plant J. 1998, 14, 225-234. [CrossRef]

26. Guevara-Morato, M.A.; de Lacoba, M.G.; Garcia-Luque, I.; Serra, M.T. Characterization of a Pathogenesis-Related Protein 4 (PR-4) Induced in Capsicum Chinense L3 Plants with Dual Rnase and Dnase Activities. J. Exp. Bot. 2010, 61, 3259-3271. [CrossRef]

27. Caporale, C.; Di Berardino, I.; Leonardi, L.; Bertini, L.; Cascone, A.; Buonocore, V.; Caruso, C. Wheat Pathogenesis-Related Proteins of Class 4 Have Ribonuclease Activity. FEBS Lett. 2004, 575, 71-76. [CrossRef]

28. Hwang, I.S.; Choi, D.S.; Kim, N.H.; Kim, D.S.; Hwang, B.K. Pathogenesis-Related Protein 4b Interacts with Leucine-Rich Repeat Protein 1 to Suppress PR4b-Triggered Cell Death and Defense Response in Pepper. Plant J. 2014, 77, 521-533. [CrossRef]

29. Despres, C.; Subramaniam, R.; Matton, D.P.; Brisson, N. The Activation of the Potato PR-Loa Gene Requires the Phosphorylation of the Nuclear Factor PBF-1. Plant Cell 1995, 7, 589-598. [CrossRef]

30. Moiseyev, G.P.; Beintema, J.J.; Fedoreyeva, L.I.; Yakovlev, G.I. High Sequence Similarity between a Ribonuclease from Ginseng Calluses and Fungus-Elicited Proteins from Parsley Indicates That Intracellular Pathogenesis-Related Proteins Are Ribonucleases. Planta 1994, 193, 470-472. [CrossRef]

31. Chiang, C.C.; Hadwiger, L.A. Cloning and Characterization of a Disease Resistance Response Gene in Pea Inducible by Fusarium Solani. Mol. Plant-Microbe Interact. 1990, 3, 78-85. [CrossRef]

32. Warner, S.A.J.; Scott, R.; Draper, J. Characterisation of a Wound-Induced Transcript from the Monocot Asparagus That Shares Similarity with a Class of Intracellular Pathogenesis-Related (PR) Proteins. Plant Mol. Biol. 1992, 19, 555-561. [CrossRef]

33. Vlot, A.C.; Dempsey, D.M.A.; Klessig, D.F. Salicylic Acid, a Multifaceted Hormone to Combat Disease. Ann. Rev. Phytopathol. 2009, 47, 177-206. [CrossRef]

34. Rochon, A.; Boyle, P.; Wignes, T.; Fobert, P.R.; Despres, C. The Coactivator Function of Arabidopsis NPR1 Requires the Core of Its Btb/Poz Domain and the Oxidation of C-Terminal Cysteines. Plant Cell 2006, 18, 3670-3685. [CrossRef]

35. Li, J.; Brader, G.; Palva, E.T. Kunitz Trypsin Inhibitor: An Antagonist of Cell Death Triggered by Phytopathogens and Fumonisin B1 in Arabidopsis. Mol. Plant 2008, 1, 482-495. [CrossRef]

36. Zimmermann, P.; Hirsch-Hoffmann, M.; Hennig, L.; Gruissem, W. Genevestigator. Arabidopsis Microarray Database and Analysis Toolbox. Plant Physiol. 2004, 136, 2621-2632. [CrossRef]

37. Chen, Z.; Silva, H.; Klessig, D.F. Active Oxygen Species in the Induction of Plant Systemic Acquired Resistance by Salicylic Acid. Science 1993, 262, 1883-1886. [CrossRef]

38. Chen, H.; McCaig, B.C.; Melotto, M.; He, S.Y.; Howe, G.A. Regulation of Plant Arginase by Wounding, Jasmonate and the Phytotoxin Coronatine. J. Biol. Chem. 2004, 279, 45998-46007. [CrossRef]

39. Delledonne, M. No News Is Good News for Plants. Curr. Opin. Plant Biol. 2005, 8, 390-396. [CrossRef] 
40. Huang, X.; Stettmaier, K.; Michel, C.; Hutzler, P.; Mueller, M.J.; Durner, J. Nitric Oxide Is Induced by Wounding and Influences Jasmonic Acid Signaling in Arabidopsis Thaliana. Planta 2004, 218, 938-946. [CrossRef]

41. O’Brien, J.A.; Daudi, A.; Butt, V.S.; Paul Bolwell, G.J.P. Reactive Oxygen Species and Their Role in Plant Defence and Cell Wall Metabolism. Planta 2012, 236, 765-779. [CrossRef]

42. Bolwell, G.P.; Butt, V.S.; Davies, D.R.; Zimmerlin, A. The Origin of the Oxidative Burst in Plants. Free Radic. Res. 1995, 23, 517-532. [CrossRef]

43. Gullner, G.; Komives, T.; Király, L.; Schröder, P. Glutathione S-Transferase Enzymes in Plant-Pathogen Interactions. Front. Plant Sci. 2018, 9, 1-19. [CrossRef]

44. Jones, A.M.E.; Thomas, V.; Bennett, M.H.; Mansfield, J.; Grant, M. Modifications to the Arabidopsis Defense Proteome Occur Prior to Significant Transcriptional Change in Response to Inoculation with Pseudomonas syringae. Plant Physiol. 2006, 142, 1603-1620. [CrossRef]

45. Serrato, A.J.; Fernández-Trijueque, J.; Barajas-López, J.-D.-D.; Chueca, A.; Sahrawy, M. Plastid Thioredoxins: A “One-for-All” Redox-Signaling System in Plants. Front. Plant Sci. 2013, 4, 463. [CrossRef]

46. Dubreuil-Maurizi, C.; Vitecek, J.; Marty, L.; Branciard, L.; Frettinger, P.; Wendehenne, D.; Meyer, A.J.; Mauch, F.; Poinssot, B. Glutathione Deficiency of the Arabidopsis Mutant Pad2-1 Affects Oxidative Stress-Related Events, Defense Gene Expression and the Hypersensitive Response. Plant Physiol. 2011, 157, 2000-2012. [CrossRef]

47. Mattoo, R.U.H.; Goloubinoff, P. Molecular Chaperones Are Nanomachines That Catalytically Unfold Misfolded and Alternatively Folded Proteins. Cell. Mol. Life Sci. 2014, 71, 3311-3325. [CrossRef]

48. Suzuki, K.; Nakanishi, H.; Bower, J.; Yoder, D.W.; Osteryoung, K.W.; Miyagishima, S.Y. Plastid Chaperonin Proteins Cpn60 Alpha and Cpn60 Beta Are Required for Plastid Division in Arabidopsis Thaliana. BMC Plant Biol. 2009, 9, 38. [CrossRef]

49. Oh, S.E.; Yeung, C.; Babaei-Rad, R.; Zhao, R. Cosuppression of the Chloroplast Localized Molecular Chaperone Hsp90.5 Impairs Plant Development and Chloroplast Biogenesis in Arabidopsis. BMC Res. Notes 2014, 7, 643. [CrossRef]

50. Schulze-Lefert, P. Plant Immunity: The Origami of Receptor Activation. Curr. Biol. 2004, 14, R22-R24. [CrossRef]

51. Hubert, D.A. Cytosolic Hsp90 Associates with and Modulates the Arabidopsis RPM1 Disease Resistance Protein. EMBO J. 2003, 22, 5679-5689. [CrossRef]

52. Liu, Y.; Burch-Smith, T.; Schiff, M.; Feng, S.; Dinesh-Kumar, S.P. Molecular Chaperone Hsp90 Associates with Resistance Protein N and Its Signaling Proteins SGT1 and Rar1 to Modulate an Innate Immune Response in Plants. J. Biol. Chem. 2004, 279, 2101-2108. [CrossRef]

53. Shirasu, K. Complex Formation, Promiscuity and Multi-Functionality: Protein Interactions in Disease-Resistance Pathways. Trends Plant Sci. 2003, 8, 252-258. [CrossRef]

54. Kadota, Y.; Shirasu, K. The Hsp90 Complex of Plants. Biochim. Biophys. Acta 2012, 1823, 689-697. [CrossRef]

55. Thomas, E.L.; van der Hoorn, R.A.L. Ten Prominent Host Proteases in Plant-Pathogen Interactions. Int. J. Mol. Sci. 2018, 19, 639. [CrossRef]

56. Shompole, S.; Jasmer, D.P. Cathepsin B-Like Cysteine Proteases Confer Intestinal Cysteine Protease Activity in Haemonchus Contortus. J. Biol. Chem. 2001, 276, 2928-2934. [CrossRef]

57. Zhao, M.; Ji, H.M.; Gao, Y.; Cao, X.X.; Mao, H.Y.; Ouyang, S.Q.; Liu, P. An Integrated Analysis of Mrna and Srna Transcriptional Profiles in Tomato Root: Insights on Tomato Wilt Disease. PLoS ONE 2018, 13, 1-18. [CrossRef]

58. Bernoux, M.; Timmers, T.; Jauneau, A.; Briere, C.; de Wit, P.J.G.M.; Marco, Y.; Deslandes, L. RD19, an Arabidopsis Cysteine Protease Required for RRS1-R-Mediated Resistance, Is Relocalized to the Nucleus by the Ralstonia Solanacearum Popp2 Effector. Plant Cell Online 2008, 20, 2252-2264. [CrossRef]

59. Koizumi, M.; Yamaguchi-Shinozaki, K.; Tsuji, H.; Shinozaki, K. Structure and Expression of Two Genes That Encode Distinct Drought-Inducible Cysteine Proteinases in Arabidopsis Thaliana. Gene 1993, 129, 175-182. [CrossRef]

60. Pieterse, C.M.; Leon-Reyes, A.; Van der Ent, S.; Van Wees, S.C. Networking by Small-Molecule Hormones in Plant Immunity. Nat. Chem. Biol. 2009, 5, 308-316. [CrossRef] 
61. Brooks, D.M.; Hernandez-Guzman, G.; Kloek, A.P.; Alarcon-Chaidez, F.; Sreedharan, A.; Rangaswamy, V.; Penaloza-Vazquez, A.; Bender, C.L.; Kunkel, B.N. Identification and Characterization of a Well-Defined Series of Coronatine Biosynthetic Mutants of Pseudomonas syringae Pv. Tomato DC3000. Mol. Plant Microbe Interact. 2004, 17, 162-174. [CrossRef]

62. Desclos-Theveniau, M.; Arnaud, D.; Huang, T.Y.; Lin, G.J.; Chen, W.Y.; Lin, Y.C.; Zimmerli, L. The Arabidopsis Lectin Receptor Kinase Lecrk-V.5 Represses Stomatal Immunity Induced by Pseudomonas syringae Pv. Tomato DC3000. PLoS Pathog. 2012, 8, e1002513. [CrossRef]

63. Chakravarthy, S.; Butcher, B.G.; Liu, Y.; D'Amico, K.; Coster, M.; Filiatrault, M.J. Virulence of Pseudomonas syringae Pv. Tomato DC3000 Is Influenced by the Catabolite Repression Control Protein Crc. Mol. Plant Microbe Interact. 2017, 30, 283-294. [CrossRef]

64. King, E.O.; Ward, M.K.; Raney, D.E. Two Simple Media for the Demonstration of Pyocyanin and Fluorescin. J. Lab. Clin. Med. 1954, 44, 301-307.

65. Betancourt, L.H.; Sanchez, A.; Pla, I.; Kuras, M.; Zhou, Q.; Andersson, R.; Marko-Varga, G. Quantitative Assessment of Urea in-Solution Lys-C/Trypsin Digestions Reveals Superior Performance at Room Temperature over Traditional Proteolysis at $37^{\circ} \mathrm{C}$. J. Proteome Res. 2018, 17, 2556-2561. [CrossRef]

66. Mertins, P.; Tang, L.C.; Krug, K.; Clark, D.J.; Gritsenko, M.A.; Chen, L.; Clauser, K.R.; Clauss, T.R.; Shah, P.; Gillette, M.A.; et al. Reproducible Workflow for Multiplexed Deep-Scale Proteome and Phosphoproteome Analysis of Tumor Tissues by Liquid Chromatography-Mass Spectrometry. Nat. Protoc. 2018, 13, 1632-1661. [CrossRef]

67. Chen, C.J.; Chen, W.Y.; Tseng, M.C.; Chen, Y.R. Tunnel Frit: A Nonmetallic in-Capillary Frit for Nanoflow Ultra High-Performance Liquid Chromatography-Mass Spectrometryapplications. Anal. Chem. 2012, 84, 297-303. [CrossRef]

68. Scheltema, R.A.; Hauschild, J.P.; Lange, O.; Hornburg, D.; Denisov, E.; Damoc, E.; Kuehn, A.; Makarov, A.; Mann, M. The Q Exactive HF, a Benchtop Mass Spectrometer with a Pre-Filter, High-Performance Quadrupole and an Ultra-High-Field Orbitrap Analyzer. Mol. Cell Proteom. 2014, 13, 3698-3708. [CrossRef]

69. Bruderer, R.; Bernhardt, O.M.; Gandhi, T.; Xuan, Y.; Sondermann, J.; Schmidt, M.; Gomez-Varela, D.; Reiter, L. Optimization of Experimental Parameters in Data-Independent Mass Spectrometry Significantly Increases Depth and Reproducibility of Results. Mol. Cell Proteom. 2017, 16, 2296-2309. [CrossRef]

70. Craig, R.; Beavis, R.C. Tandem: Matching Proteins with Tandem Mass Spectra. Bioinformatics 2004, 20, 1466-1467. [CrossRef]

71. Eng, J.K.; Jahan, T.A.; Hoopmann, M.R. Comet: An Open-Source MS/MS Sequence Database Search Tool. Proteomics 2013, 13, 22-24. [CrossRef]

72. Deutsch, E.W.; Mendoza, L.; Shteynberg, D.; Slagel, J.; Sun, Z.; Moritz, R.L. Trans-Proteomic Pipeline, a Standardized Data Processing Pipeline for Large-Scale Reproducible Proteomics Informatics. Proteom. Clin. Appl. 2015, 9, 745-754. [CrossRef]

73. Röst, H.L.; Sachsenberg, T.; Aiche, S.; Bielow, C.; Weisser, H.; Aicheler, F.; Andreotti, S.; Ehrlich, H.C.; Gutenbrunner, P.; Kenar, E.; et al. OpenMS: A Flexible Open-Source Software Platform for Mass Spectrometry Data Analysis. Nat. Methods 2016, 13, 741-748. [CrossRef]

74. Röst, H.L.; Rosenberger, G.; Navarro, P.; Gillet, L.; Miladinović, S.M.; Schubert, O.T.; Wolski, W.; Collins, B.C.; Malmström, J.; Malmström, L.; et al. OpenSWATH Enables Automated, Targeted Analysis of DataIndependent Acquisition MS Data. Nat. Biotechnol. 2014, 32, 219-223. [CrossRef]

75. Lambert, J.P.; Ivosev, G.; Couzens, A.L.; Larsen, B.; Taipale, M.; Lin, Z.Y.; Zhong, Q.; Lindquist, S.; Vidal, M.; Aebersold, R.; et al. Mapping Differential Interactomes by Affinity Purification Coupled with Data-Independent Mass Spectrometry Acquisition. Nat. Methods 2013, 10, 1239-1245. [CrossRef]

76. Mi, H.; Huang, X.; Muruganujan, A.; Tang, H.; Mills, C.; Kang, D.; Thomas, P.D. Panther Version 11: Expanded Annotation Data from Gene Ontology and Reactome Pathways and Data Analysis Tool Enhancements. Nucleic Acids Res. 2017, 45, 183-189. [CrossRef]

77. Mi, H.; Muruganujan, A.; Casagrande, J.T.; Thomas, P.D. Large-Scale Gene Function Analysis with the Panther Classification System. Nat. Protoc. 2013, 8, 1551-1566. [CrossRef]

78. Huang, D.W.; Sherman, B.T.; Lempicki, R.A. Bioinformatics Enrichment Tools: Paths toward the Comprehensive Functional Analysis of Large Gene Lists. Nucleic Acids Res. 2009, 37, 1-13. [CrossRef] 
79. Huang, D.W.; Sherman, B.T.; Lempicki, R.A. Systematic and Integrative Analysis of Large Gene Lists Using David Bioinformatics Resources. Nat. Protoc. 2009, 4, 44-57. [CrossRef]

80. Vizcaino, J.A.; Cote, R.G.; Csordas, A.; Dianes, J.A.; Fabregat, A.; Foster, J.M.; Griss, J.; Alpi, E.; Birim, M.; Contell, J.; et al. The Proteomics Identifications (PRIDE) Database and Associated Tools: Status in 2013. Nucleic Acids Res. 2013, 41, D1063-D1069. [CrossRef] 